\title{
DIGITALCOMMONS
}

@WAYNESTATE-

Wayne State University

Law Faculty Research Publications

Law School

$1-1-2007$

\section{The Constitution, the Courts and the Common Law}

Robert A. Sedler

Wayne State University, rsedler@wayne.edu

\section{Recommended Citation}

Robert A. Sedler, The Constitution, the Courts and the Common Law, 53 Wayne L. Rev. 153 (2007).

Available at: http://digitalcommons.wayne.edu/lawfrp/88

This Article is brought to you for free and open access by the Law School at DigitalCommons@WayneState. It has been accepted for inclusion in Law Faculty Research Publications by an authorized administrator of DigitalCommons@WayneState. 


\title{
THE CONSTITUTION, THE COURTS AND THE COMMON LAW
}

\author{
ROBERT A. SEDLER ${ }^{\dagger}$ \\ Table of Contents
}

I. INTRODUCTION: THE JUdicial POWER To ESTABLISH AND DEVELOP

THE COMMON LAW $\ldots \ldots \ldots \ldots \ldots \ldots \ldots \ldots \ldots \ldots \ldots$

II. JUDICIAL POLICYMAKING AND THE DEVELOPMENT OF THE

COMMON LAW IN MiCHIGAN $\ldots \ldots \ldots \ldots \ldots \ldots \ldots \ldots \ldots$

A. Liability-Limiting Rules $\ldots \ldots \ldots \ldots \ldots \ldots \ldots \ldots \ldots$

B. The Expansion of Tort Liability in Michigan ......... 166

C. The Last Quarter-Century: The Question of Where Policy

Considerations Lead .......................... 169

D. Judicial Policymaking in Michigan: Some Further

Observations ........................ 175

III. ThE Michigan SUPREME COURT DECISION IN HENRY V. DOW

CHEMICAL . . . . . . . . . . . . . . . . . . . . . 177

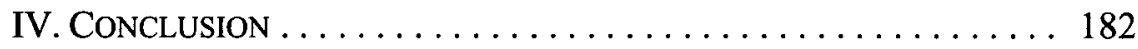

I. INTRODUCTION: THE JUdiCIAL POWER TO ESTABLISH AND DEVELOP THE COMMON LAW

The Michigan Constitution provides for separation of powers, ${ }^{1}$ and further provides that the judicial power of the state is vested exclusively in one court of justice. ${ }^{2}$ A major component of judicial power is the authority of the courts to establish and develop the common law of the state. This has been the traditional function of the courts in the Anglo-American legal system, and the common law has often been described as "judge-made law." At the same time, the legislature has the power to change the common law by legislation and thus has the ultimate responsibility to determine the law of the state. ${ }^{3}$ But in the absence of legislation changing the

${ }^{\dagger}$ Distinguished Professor of Law, Wayne State University. A.B., 1956; J.D., 1959, University of Pittsburgh.

1. MICH. CONST. art III, $\S 2$.

2. MICH. CONST, art. VI, $\S 1$.

3. See the classic discussion of legislative power in Bowerman v. Sheehan, $242 \mathrm{Mich}$. 95, 98, 219 N.W. 69, 70 (1928) (citations omitted). The court there stated:

The legislature may alter or repeal the common law. It may create new offenses, enlarge the scope of civil remedies, and fasten responsibility for injuries upon 
common law, it is the common law that determines the legal rights and obligations of private persons, and the largest part of private law in Michigan and elsewhere is the common law. ${ }^{4}$

persons against whom the common law gives no remedy ... . A person has no property, no vested interest, in any rule of the common law. That is only one of the forms of municipal law, and is no more sacred than any other. Rights of property which have been created by the common law cannot be taken away without due process; but the law itself, as a rule of conduct, may be changed at the will $* * *$ of the Legislature, unless prevented by constitutional limitations. Indeed, the great office of statutes is to remedy defects in the common law as they are developed, and to adapt it to the changes of time and circumstances.

Id.

In that case, the court upheld the power of the legislature to impose liability against an automobile owner for harm caused by members of his immediate family.

A good example of legislative power to change the common law in Michigan is the matter of governmental tort immunity. While the Michigan Supreme Court has abolished the common law doctrine of governmental tort immunity, see Williams v. City of Detroit, 364 Mich. 231, 111 N.W.2d 1 (1961); Pittman v. City of Taylor, 398 Mich. 41, 247 N.W.2d 512 (1976), the Michigan Legislature has enacted a comprehensive statute regulating the tort liability of governmental entities and their employees. MicH. COMP. LAws ANN. $\S \S$ 691.1401-.1415(West 2000 \& Supp. 2007).. See Thomas v. State Highway Dept., 398 Mich. 1, 247 N.W.2d 530 (1976).

Roscoe Pound, one of the Nation's foremost legal scholars, has explained the relationship between the common law and legislation in terms of the common law as being the traditional element of the law and legislation as being the enacted or imperative element of the law. Pound saw these elements as being closely interrelated.

Over time, Pound explained, as judicial experience develops the common law into clear principles, these principles are incorporated into legislative rules, which in the process of time become absorbed into the legal system and are themselves interpreted and developed by the common law, which fills the gaps in legislation and further develops the principles of legislation.

Neil Hamilton \& Mathias alfred Jaren, Introduction to Roscoe Pound, The SPIRIT OF THE COMMON LAW xxxiii (Transaction ed. 1999). The authors cited to Roscoe Pound, Theories of Law, 22 YALE L.J. 114, 143 (1912). This book, a seminal work on the common law, was first published in 1921 and was based on the lectures that Pound delivered at Dartmouth College in the summer of that year.

4. The common law in force at the time of the 1963 Constitution remains in force unless and until it is changed by legislation or judicial decision. MiCH. CONST. art III, $\S 7$. See Myers v. Genesee County Auditor, 375 Mich. 1, 7, 133 N.W.2d 190, 191 (1965). This provision traces back to Michigan's first Constitution of 1835, where it was provided that, "[a]ll laws now in force in the territory of Michigan, which are not repugnant to this constitution, shall remain in force until they expire by their own limitations, or be altered or repealed by the legislature." MICH. CONST. art. XIII, sched. 2(1835). It has been assumed that the reference to [a]ll laws now in force" included the common law, and following statehood, the newly-established state courts applied the common law in the same manner as it had been applied by the territorial courts prior to statehood.

The Michigan Supreme Court has recently observed that, "Michigan courts have uniformly held that legislative amendment of the common law is not lightly presumed." 
There is now a question in Michigan as to whether separation of powers considerations should impose significant limits on the power of the courts to establish and develop the common law of Michigan. Specifically, the question is whether the courts should be constrained by separation of powers considerations from engaging in what has been called judicial policymaking in formulating common law rules. The proposition, set forth in Justice Corrigan's opinion for the Michigan Supreme Court in Henry v. Dow Chemical Co., ${ }^{5}$ and in a law review article by Michigan Supreme Court Justice Robert P. Young, Jr., ${ }^{6}$ is that policymaking is exclusively the province of the legislature, so that the courts cannot formulate common law rules that may have significant social and economic effects, and that the courts should not make a "new and potentially societally dislocating change to the common law." "Justice Corrigan stated:

In certain instances, the principle of separation of powers is an affirmative constitutional bar on policy-making by this Court. In other cases, however, the separation of powers considerations may operate as a prudential bar to judicial policy-making in the common-law arena. This is so when we are asked to modify the common law in a way that may lead to dramatic reallocation of societal benefits and burdens. ${ }^{8}$

Similarly, as Justice Young has stated:

[T]he judiciary is largely institutionally incompetent-or at the very least, severely "challenged"- to make sound policy choices. Because the executive and legislative branches are specifically

Wold Architects and Engineers v. Strat, 474 Mich. 223, 233, 713 N.W.2d 750, 756 (2006). In Michigan, as elsewhere, it is a fundamental principle of statutory construction that, "statutes in derogation of the common law must be strictly construed, ... and will not be extended by implication to abrogate established rules of common law." Theophelis $\mathrm{v}$. Lansing General Hosp., 430 Mich. 473, 488, 424 N.W.2d 478, 484-85 (1988). In Theophelis the court held that a 1974 amendment to the Michigan contribution among joint tortfeasors act did not abrogate the common law rule that settlement with, and release of, an agent operates to discharge the principal from vicarious liability for the agent's acts. Id. at 491, 424 N.W.2d at 486; Mich. COMP. LAWs ANN. § 600.2925d (West 2000).

5. 473 Mich. 63, 701 N.W.2d 684 (2005).

6. Robert P. Young, Jr., State Jurisprudence, the Role of the Courts and the Rule of Law, 8 TEX. REV. LAW \& POL. 299 (2004).

7. Henry, 473 Mich. at 89,701 N.W.2d at 697.

8. Id. (footnotes omitted). 
designed to create policy, it is entirely desirable, and most consistent with our constitutional values, that important public and social policy be made by these political branches of government instead of the judiciary. ${ }^{9}$

Justice Young appears to be going even beyond prudential considerations to constitutional limitations, maintaining that, "[t]his modern conception of the common law that authorizes jurists to discover, create, or modify common-law rules-or policy - is entirely inconsistent with normative constitutional policies and principles, according to which prerogatives of policymaking are given to other branches of government." 10

The author strongly disagrees with the proposition that there is any kind of constitutional constraint, either prudential or structural, on the power and indeed the constitutional responsibility of the Michigan courts to engage in judicial policymaking in the process of formulating common law rules. The judicial power given to the Michigan courts by the Michigan Constitution includes the power to do what courts have always done in the AngloAmerican legal system. The judicial power gives the courts the responsibility to adjudicate controversies between private persons and in the process to develop a common law through the workings of binding precedent and stare decisis. In so doing, the courts may properly take into account considerations of social and economic policy just as the legislature does when it engages in the process of enacting legislation. The difference between what the courts do and what the legislature does is a difference in process, not a difference in substance. ${ }^{11}$ Judicial policymaking

9. Young, supra note 6, at 304.

10. Id. at 302 .

11. In his classic work on judicial decision-making, United States Supreme Court Justice Benjamin N. Cardozo carefully delineated the similarities and differences between legislative and judicial activity. BENJAMIN N. CARDOZO, THE NATURE OF THE JUDICIAL PROCESS 119-20 (Yale University Press) (1921) (basing this book on the Storrs Lectures delivered at Yale University in 1921 when Justice Cardozo was a Judge of the New York Court of Appeals). He says that, "Everywhere there is a growing emphasis on the analogy between the function of the judge and the function of the legislator." He then says that this analogy has been developed by the French legal philosopher Francois Geny "with boldness and power," and goes on to quote extensively from Geny's work:

A priori the process of research (la recherche), which is imposed upon the judge in finding the law seems to us very analogous to that incumbent on the legislator himself. Except for this circumstance, certainly not negligible, and yet of secondary importance, that the process is set in motion by some concrete situations, and in order to adapt the law to that situation, the considerations which ought to guide it are, in respect of the final end to be attained, exactly of the same nature as those which ought to dominate legislative action itself, since it is a 
question in each case, of satisfying, as best may be, justice and social utility by an appropriate rule. Hence, I will not hesitate in the silence or inadequacy of formal sources, to indicate as the general line of direction for the judge the following: that he sought to shape his judgment of the law in obedience to the same aims which would be those of a legislator who was proposing to himself to regulate the question. None the less, an important distinction separates here judicial from legislative activity. While the legislator is not hampered by any limitations in the appreciation of a general situation, which he regulates in a manner altogether abstract, the judge, who decides in view of particular cases, and with reference to problems absolutely concrete, ought, in adherence to the spirit of our modern organization, and in order to escape the dangers of arbitrary action, to disengage himself, so far as possible, of every influence that is personal or that comes from the particular situation which is presented to him, and base his judicial decision on elements of an objective nature. And that is why the activity which is proper to him has seemed to me capable of being justly qualified: free scientific research, libre recherche scientifique: free, since it is removed from the action of positive authority; scientific, at the same time, because it can find its solid foundations only in the objective elements which science alone is able to reveal to it.

Methode D'Interpretation et Sources en Droit Prive Positif, vol. II, 77 (Penguin Modern Legal Philosophy Series) (transl. 1919).

Cardozo also compared the differences between how the judge and the legislator went about balancing the social interest served by symmetry or certainty against the social interest served by equity and fairness or other elements of social welfare. He stated as follows: If you ask how he is to know when one interest outweighs another, I can only answer he must get his knowledge just as the legislator gets it, from experience and study and reflection; in brief, from life itself. Here, indeed, is the point of contact between the legislator's work and his. The choice of methods, the appraisement of values, must in the end be guided by like considerations for the one as for the other. Each indeed is legislating within the limits of his competence. No doubt the limits for the judge are narrower. He legislates only between gaps. He fills the open spaces in the law. How far he may go without traveling beyond the walls of the interstices cannot be staked out for him upon a chart. He must learn it for himself as he gains the sense of fitness and proportion that comes with years of habitude in the practice of an art. Even within the gaps, restrictions not easy to define, but felt, however, impalpable they may be, by every judge and lawyer, hedge and circumscribe his action. They are established by the traditions of the centuries, by the example of other judges, his predecessors and his colleagues, by the collective judgment of the profession, and by the duty of adherence to the pervading spirit of the law.

CARdozo, The Nature of THE JUdiClal Process, supra note 11, at 113-14.

Cardozo concludes by emphasizing the limitations imposed on a judge by the judicial process itself:

The judge, even when he is free, is still not wholly free. He is not to innovate at pleasure. He is not a knight-errant roaming at will in pursuit of his own ideal of beauty or of goodness. He is to draw his inspiration from consecrated principles. $\mathrm{He}$ is not to yield to spasmodic sentiment, to a vague and unregulated benevolence. He is to exercise a discretion informed by tradition, methodized by analogy, disciplined by system, and subordinated to 'the primordial necessity of 
takes place within the judicial process, that is, in the adjudication of controversies between persons in which the courts promulgate common law rules. The common law develops in a line of growth through the workings of binding precedent and stare decisis, and to the extent that there are limitations on the development of the common law, these are limitations that inhere in the judicial process itself. ${ }^{12}$ When the courts, for example, consider whether a new claim or a new defense should be recognized by the common law, they must consider whether that new claim or defense properly follows in the line of growth from existing doctrine and precedent. ${ }^{13}$ But if the courts conclude that it does, that is, if the claim or defense is consistent with the line of growth of existing doctrine and precedent, then the courts are not constrained from recognizing the claim or defense on the ground that the substance of the claim or defense is a matter for the legislature, rather than for the courts, or that the resulting

order in the social life.' Wide enough in all conscience is the field of discretion that remains.'

Id. at 140-41 (citation omitted).

12. As Pound has observed:

The doctrine of precedents means that causes are to be judged by principles reached inductively from the judicial experience of the past, not by deduction established arbitrarily by sovereign will. In other words, reason, not arbitrary will is to be the ultimate ground of decision... The common-law doctrine is one of reason applied to experience. It assumes that experience will afford the most satisfactory foundation for standards of action and principles of decision. It holds that law is not to be made arbitrarily by a fiat of sovereign will, but is to be discovered by judicial and juristic experience of the rules and principles which in the past have accomplished or failed to accomplish justice. Where such a doctrine obtains, not merely the interpretation and application of legal rules but in large measure the ascertainment of them must be left to the disciplined reason of the judges, and we must find in the criticism of the reported decision by bench and bar in other cases our assurance that they will be governed by reason and that the personal equation of the individual judge will be suppressed. The vitality of the common law and the steady increase in the value attributed to judicial decisions in the rest of the world attest the soundness of this explanation.

HAMILTON \& JAREN, SPIRIT OF THE COMMON LAW, supra note 3, at 182-83.

13. See the discussion of the function of precedent in the judicial decision making in CARDOZo, THE NATURE OF THE JUdiCIAL Process, supra note 11, at 113-14. at 149-52. Cardozo maintains that adherence to precedent should be the rule and not the exception, but that:

$[T]$ here should be greater rediness to abandon an untenable position when the rule to be discarded may not reasonably be supposed to have determined the conduct of the litigants, and particularly when in its origin it was the product of institutions or conditions which have gained a new significance or development with the progress of the years.

Id. 
common law rule may have significant social and economic effects.

The legislature, in contrast, enacts legislation through the legislative process. That process is a freewheeling one, often dependent on political compromise and completely unrestrained by the kind of limitations that inhere in the judicial process. There is no legislative concept of line of growth, and the legislature can and often does enact legislation that brings about fundamental societal change or reverses the course of public policy. In our constitutional system, the most important questions of public policy are, of course, determined by the legislature. ${ }^{14}$ Where the

14. Because this is so, a court may be reluctant to formulate a common law rule involving important considerations of public policy where it is not absolutely necessary for the court to do so. This situation was presented in a case before a Michigan federal court, Odgers v. Ortho Pharm. Corp., 609 F.Supp. 867 (E.D.Mich. 1985), in which the federal court certified an uncertain question of Michigan law to the Michigan Supreme Court. That question was whether the manufacturer of an oral contraceptive, which is a prescription drug, in addition to its duty under the common law of Michigan to warn physicians of any risks inherent in the use of the oral contraceptive, had an additional common law duty to provide adequate warnings directly to the users of the oral contraceptives. Odgers, 609 F.Supp. at 868-69. However, in In re Certified Questions, a divided Michigan Supreme Court held 4-3, that it would refuse to answer a question certified to it by a federal court in Michigan as to whether a manufacturer of prescription drugs has a duty to disclose the risks and side effects of the drugs directly to the patient. 419 Mich. 686, 358 N.W.2d 873 (1984). Writing for the majority, Justice Levin maintained that:

The allocation of the duty to warn patients is a public policy question involving the marketing system and economics of a major industry and the everyday practice of an essential profession. We believe that the Legislature is in a better position to allocate those duties. If, because of legislative inaction, this Court is constrained to make the choices necessary for deciding this question, it would be better to do so in a case where the factual record is fully developed, and where the history of proceedings in the courts of this state provide more assurance than the records of these proceedings that the decision of the Court responds to all the issues implicated by the questions posed.

Id. at $691-92,358$ N.W.2d at 874 . Thus, the Michigan Supreme Court advised the federal court that the Michigan courts have announced no rule of law on the certified questions. The dissenting justices, in an opinion by Justice Boyle, maintained that the court could decide the questions on the basis of the record and would have promulgated the following common law rule: in addition to its duty to warn the prescribing physician, the manufacturer of an oral contraceptive has a duty to warn the user directly of known hazards, but the manufacturer of a therapeutic, diagnostic or curative drug does not have this additional duty. $I d$. at 699,358 N.W.2d at 878 . It should be noted that Justice Levin, writing for the Court, recognized that where the legislature had not acted on an important matter of public policy, the courts had the power to do so by way of a common law rule. His point was that the Court should not do so in the context of answering a certified question instead of in the context of resolving an actual case where the question was directly presented.

However, the luxury of avoiding a decision on what the rule of Michigan law was in this case was not open to the United States District Court for the Eastern District of 
legislature disagrees with the policy choices reflected in a common law rule, the legislature has the power to enact legislation changing the common law rule. But there are many areas of private law where the legislature has not acted. In our constitutional system, where the matter in issue is not covered or preempted by legislation, the courts may formulate a common law rule to cover that matter, and in so doing may engage in judicial policymaking. Judicial policymaking is a part of the development of the common law, and the courts cannot avoid their responsibility to engage in judicial policymaking to the extent that it is necessary in the process of formulating the common law. As a constitutional matter, there are no separation of powers considerations that prohibit the courts from engaging in judicial policymaking.

Considerations of separation of powers do constrain the power of the courts to formulate common law rules in two ways. First, and most obviously, since under the Michigan Constitution legislation takes precedence over the common law, the courts may not formulate a common law rule that expressly conflicts with the provisions of legislation. ${ }^{15}$ Second,

Michigan. That court did have to resolve an actual case where the question was directly presented and so had to make a determination of Michigan law on the point in issue. Since a federal court sitting in diversity must apply the law of the state in which it sits as declared by the highest state court, Erie R.R. Co. v. Tompkins, 304 U.S. 64 (1938), it follows that the primary responsibility for determining the law of Michigan in this case fell on the Michigan Supreme Court, not on the federal court that certified the question of Michigan law to the Michigan Supreme Court. The Michigan Supreme Court refused to exercise that responsibility, knowing full well that in this case the federal court would have to decide what the rule of Michigan law was. In every sense, the refusal of the Michigan Supreme Court to answer the certified question in this case was an abdication of the state court's responsibility to declare the law of the state and is inconsistent with the function of a state's highest court in the American federal system.

When the case was returned to the federal district court with the state law question unanswered, the federal judge by necessity was compelled to make an "educated guess" and predict how the Michigan Supreme Court would decide this question if it were presented to it in the future. Federal District Judge Avern Cohn made this prediction in light of "the policies involved in this litigation under the facts of the present case." Odgers, 609 F.Supp. at 869. In a very careful and precise analysis of the issue from this perspective, Judge Cohn, emphasizing, as did the dissenting Justices in Certified Questions, the fact that the patient rather than the physician made the primary choice whether or not to obtain a prescription for an oral contraceptive, predicted that "the Michigan Supreme Court would impose the duty on the manufacturer of an oral contraceptive to warn consumers directly of the possible side effects associated with their use when required to decide this issue." Id. at 872.

15. Legislation and the common law may interact with each other. The common law, of course, applies to cases arising before the effective date of legislation. However, the courts have the discretion to apply the provisions of the new legislation to those cases as a common law rule in the absence of any issue of detrimental reliance on the former common law rule. See e.g., Kovacs v. Chesapeake \& Ohio Ry. Co., 426 Mich. 647, 397 N.W.2d 169 
the courts may not properly formulate a common law rule in an area that has been effectively preempted by legislation, even though the common law rule does not expressly conflict with the legislation. ${ }^{16}$ An example of preemption in Michigan is in the area of liability of a bar owner for harm caused by serving liquor to an intoxicated patron. The Michigan Supreme Court has found that the legislature has enacted a comprehensive dram shop act designed to change the common law rule of nonliability of the bar owner for harm caused by intoxicated patrons. ${ }^{17}$ The act provides for recovery against the bar owner by all persons injured by the intoxicated patron, including the patron's spouse, child, parent or guardian. ${ }^{18}$ But the act does not provide for recovery against the bar owner by the intoxicated patron herself on a theory of gross negligence or wilful misconduct. ${ }^{19}$ The Michigan Supreme Court has found that "the Legislature intended the dramshop act to be a complete and self-contained solution to a social problem not adequately addressed at common law. ${ }^{20}$ Thus, the dram shop

(1986). In that case, the court relied on the fact that the newly enacted statute regulating damages for wrongful death reduced future damages to present value by a $5 \%$ factor to reject the defendant's argument that the court should use a $12 \%$ factor. In addition, since the legislation did not provide that the jury should be informed that the award was not subject to income tax, the court would not consider the defendant's argument that it be so instructed. Id. at $649-50,397$ N.W.2d at $169-70$.

Conversely, the legislature may enact legislation codifying a common law rule, as it did with respect to the former doctrine of governmental immunity (see Pittman v. City of Taylor, 398 Mich. 41, 247 N.W.2d 512 (1976)), and with respect to the adoption of a rule of comparative negligence in place of contributory negligence. See Placek v. City of Sterling Heights, 405 Mich. 638, 275 N.W.2d 511 (1979), and the discussion, infra, notes 53, 57, and accompanying text.

16. Jackson v. PKM Corp., 430 Mich. 262, 422 N.W.2d 657 (1988).

17. MICH. COMP. LAWS ANN. $\$ 436.1801$ (West 2001).

18. Id.

19. Id.

20. Browder v. Int'l. Fidelity Ins. Co., 413 Mich. 603, 615, 321 N.W.2d 668, 675 (1982). In that case, the court held that the dramshop act's two year statute of limitations applied in an action against the bar owner's insurer for injuries caused by an intoxicated patron of the bar, and that the plaintiff could not bring her claim under the six year statute of limitations for contract actions by characterizing her claim as one in contract as the third party beneficiary of the insurance contract between the bar and the insurer. Id. at 616,321 N.W.2d at 675. Similarly, in Millross v. Plum Hollow Golf Club, the court held that the dramshop act preempts negligence claims based the furnishing of liquor to an intoxicated person, such as a claim of negligent supervision of an employee who became intoxicated at a function he was required to attend by his employer. 429 Mich. 178, 183, 413 N.W.2d 17, 19 (1987). It observed that "[i]n general, where comprehensive legislation prescribes in detail a course of conduct to pursue and the parties and things affected, ... the Legislature will be found to have intended that the statute supersede and replace the common law dealing with the subject matter." Id. 
act has effectively preempted the area of the bar owner's liability for harm caused by the serving of liquor to an intoxicated patron, and since the act does not allow recovery against the bar owner by the intoxicated patron herself, the courts cannot formulate a common law rule allowing such recovery. ${ }^{21}$ However, where the substance of the matter in issue is not

21. Jackson, 430 Mich. 262, 422 N.W.2d 657. The dramshop act does not preempt a common law claim against a bar owner unrelated to the furnishing of liquor to an intoxicated person, such as a claim of negligence in failing to maintain a suitable place and safe conditions for business invitees. Manual v. Weitzman, 386 Mich. 157, 164-65, 191 N.W.2d 474,477 (1971). In that case, liability was based on the failure of the bar owner to prevent an intoxicated patron from assaulting another patron. Id. at 160, 191 N.W.2d 475. See also Mann v. Shusteric Enterprises, 470 Mich. 320, 683 N.W.2d 573 (2004) (holding that although the dramshop act did not preempt a common law claim for negligence against a bar owner by an intoxicated patron who suffered injury after slipping and falling in the bar's parking lot, the bar's knowledge of the patron's intoxication was not relevant on the issue of whether the bar breached its duty to protect the patron against the ice and snow in the parking lot).

In contrast, the Michigan dog bite statute, MICH. COMP. LAWS ANN. § 287.351 (West 2003), has been held not to preempt a common law action for negligence against the dog owner. Nicholes v. Lorenz, 396 Mich. 53, 59-60, 237 N.W.2d 468, 470 (1976). Instead, the court found that the legislature intended to provide alternative means of recovery for harm caused by dog bites. Id. The dog bite statute imposes strict liability except where the dog has been provoked, in which case there is no liability. MICH. COMP. LAWS ANN. $\$ 287.351$. The claim for common law negligence is available where recovery cannot be had under the statute because the dog has been provoked (the provocation barring recovery can be unintentional), but the owner has been negligent and the plaintiff's recovery will be reduced by the plaintiff's comparative fault, if any. Hill v. Hoig, 258 Mich. App. 538, 540-41, 672 N.W.2d 531, 532-33 (2003). The Michigan Supreme Court has recently held that the Michigan Arbitration Act, MICH. CoMP. LAWS ANN. §600.5001 (West 2000), did not preempt common law arbitration in Michigan, and that when the parties' agreement to arbitrate does not comply with statutory requirements, the parties are deemed to have agreed to a common law arbitration. Wold Architects and Engineers v. Strat, 474 Mich. 223, 713 N.W.2d 750 (2006).

In Van v. Zahorik, a sharply divided Michigan Supreme Court held in a 4-3 decision that the Child Custody Act, MiCH. COMP. LAwS ANN. $§ \S 722.21-.31$ (West 2002), occupied the field of child custody to the extent of precluding the court from recognizing as a matter of common law a claim of equitable parenthood or equitable estoppel, asserted by a person with a longstanding relationship to a child, but who was not a biological or legal parent of the child and who was not related by marriage to the child's biological parent. 460 Mich. 320,597 N.W.2d 15 (1999). The court concluded that the legislature had provided a comprehensive statutory scheme to deal with all issues relating to child custody in the act, and that, "in the context of a subject matter fraught with public policy implications and the Legislature's occupation of the field of child custody with the promulgation of the Child Custody Act ..., [t] the creation and extension of rights relating to child custody matters is clearly the province of the Legislature, not the judiciary." Id., 460 Mich. at 330,597 N.W.2d at 20. The dissenting justices argued that the Child Custody Act did not "supplant or preempt the subject of visitation or the equitable powers of the circuit court to determine visitation 
covered by or preempted by legislation, the courts may properly formulate a common law rule covering that matter, and in so doing, they may make policy determinations.

The history of the development of the common law in the United States has been a history of judicial policymaking. The role of judicial policymaking in the development of the common law has been expounded many years ago by the venerated jurist Oliver Wendell Holmes in his classic work, THE COMMON LAW. Holmes begins the book by discussing the role of experience and public policy in "the life of the Law."

The life of the Law has not been logic: it has been experience. The felt necessities of the time, the prevalent moral and political theories, intuitions of public policy, avowed or unconscious, even the prejudices which judges share with their fellow men, have had a good deal more to do than the syllogism in determining the rules by which men should be governed. ${ }^{22}$

In commenting on this passage Harvard Professor Mark De Wolfe Howe, who edited the 1963 edition of The Common Law, observed that: "[e]arly in the 1870 's [Holmes] had come to recognize the sterility of a jurisprudence that disregards the social, psychological, and moral conditions from which the law draws its vivifying juices." ${ }^{23}$ In Holmes' view, whenever a jurist was concerned with the formulation of new rules of law or with the enforcement of inherited doctrine, the critical question for the jurist should be "[w] hat rule of law will best serve the interests of this society?"24

Holmes went on to discuss the role of public policy in the development of the common law and the similarity between the common law and legislation in terms of public policy. Holmes stated:

In substance the growth of the law is legislative. And this in a deeper sense than that what the courts declare to have always been the law is in fact new. It is legislative in its grounds. The very

under circumstances not expressly included within the statute." Id. at 340,597 N.W.2d at 25. (Brickley, J., dissenting). This being so, the dissent argued that the courts were not precluded from extending equitable parenthood to a person who acted as the children's parent in the erroneous belief that he was their biological father. Id. at 345,597 N.W. $2 \mathrm{~d}$ at 27 (Kelly, J., dissenting).

22. Oliver WENDELl Holmes, THE COMmONLAW 5 (Mark DeWolfe Howe ed., 1963) (1881). THE COMMON LAW was originally published in 1881. It consists of eleven lectures that Holmes delivered at the Lowell Institute in Boston.

23. Id. at xxiii.

24. Id. 
considerations which judges most rarely mention, and always with an apology, are the secret root from which the law draws all the juices of life. I mean, of course, considerations of what is expedient for the community concerned. Every important principle which is developed by litigation is in fact and at bottom the result of more or less definitely understood views of public policy; most generally, to be sure, under our practices and traditions, the unconscious result of instinctive preferences and inarticulate traditions, but none the less traceable to views of public policy in the last analysis. ${ }^{25}$

As the above discussion makes clear, when courts today engage in what has been called judicial policymaking, they are doing exactly what Holmes said that courts did and should do in the performance of the judicial function to establish and develop the common law. ${ }^{26}$

25. Id. at 32. Holmes insists that there should be a conscious recognition of the legislative function of the courts, and that the law "is always approaching, and never reaching consistency."

"It is forever adopting new principles from life at one end, and it always retains old ones from history at the other, which have not yet been absorbed or sloughed off. It will become entirely consistent only when it ceases to grow. However much we may codify the law into a series of seemingly self-sufficient propositions, Id. those propositions will be but a phase in a continuous growth."

26. Holmes' views on the common law and judicial policymaking were echoed in later years by Pound and Cardozo. Pound referred to judicial empiricism, stating as follows:

The infusion of morals into the law through the development of equity was not an achievement of legislation, it was the work of the courts. The absorption of the usages of merchants into the law was not brought about by statutes but by judicial decisions. When once the current of juristic thought and judicial decision is turned into the new course our Anglo-American method of judicial empiricism has always proved adequate. Given new premises, our common law has the means of developing them to meet the exigencies of justice and of molding the results into a scientific system. Moreover, it has the power of acquiring new premises, as it did in the development of equity and the absorption of the law merchant. Indeed fundamental changes in our legal system almost unnoticed, and a shifting was in progress in our case law from the individualist justice of the nineteenth century, which has passed so significantly by the name of legal justice, to the social justice of today even before the change in our legislative policy became so marked.

HAMILTON \& JAREN, THE SPIRIT OF THE COMMON LAW, supra note 3, at 184-85.

Cardozo advocated the use of what he called the method of sociology in judicial decision. As he stated:

Insignificant is the power of innovation of any judge, when compared with the bulk and pressure of rules that hedge him on every side. Innovate, however, to some extent he must, for with new conditions, there must be new rules. All that the method of sociology demands is that within this narrow range of choice he 


\section{Judicial Policymaking and THE Development of THE COMMON LAW IN MICHIGAN}

\section{A. Liability-Limiting Rules}

Perhaps the clearest historical example of judicial policymaking in the development of the common law is the liability-limiting rules of the late nineteenth century that were promulgated in the wake of the Industrial Revolution to protect the newly-emerging industries. ${ }^{27}$ The general principles of the common law imposed liability for negligence based on the three elements of breach of duty, causation, and harm. The courts grafted on to these general principles liability-limiting rules such as assumption of risk, contributory negligence, and the fellow servant doctrine, all of which had the effect of denying recovery to workers and other victims of industrial negligence. In speaking of the origins of doctrine of contributory negligence, for example, former Michigan Supreme Court Justice G. Mennan Williams observed:

Basically, the commentators have agreed that the most plausible explanation for the origin of the doctrine was the period of individualism and rapid development known as the Industrial Revolution. The policy, it is said, was designed to protect infant industries "from oversympathetic juries who regarded these corporation defendants as intruders, as well as immensely rich." 28

Similarly when the Michigan Supreme Court abandoned the common law

shall search for social justice.

CARDOZO, THE NATURE OF THE JUdiClal PROCESS, supra note 11, at 136-37.

27. Judicial policymaking at this point in time was also found in the numerous decisions of the Michigan Supreme Court refusing to enforce certain contracts on the ground that they were "void as a matter of public policy." See, e.g., Jordan v. Westerman, 62 Mich. 170,28 N.W. 826 (1886) (refusing to enforce contract by which lawyers would receive a share of alimony awarded in divorce proceeding); McNamara v. Gargett, 68 Mich. 454, 36 N.W. 218 (1888) (refusing to enforce contract containing illegal consideration); Case v. Smith, 107 Mich. 416, 65 N.W. 279 (1895) (refusing to enforce promissory note issued in exchange for promise to conceal from public fact that maker's spouse has been guilty of adultery); Vreeland v. Turner, 117 Mich. 366, 75 N.W. 937 (1898) (refusing to enforce contract under which one of the creditors of an insolvent estate withdrew his assistance from a suit brought by all the creditors upon the insolvent's promise to pay his claim); Conklin v. Conklin, 165 Mich. 571, 131 N.W. 154 (1911) (denying contract by which parties agreed to try to persuade a court that a will was valid when they believed that it was invalid).

28. Kirby v. Larson, 400 Mich. 585, 622, 256 N.W.2d 400, 418 (1977) (Opinion of Williams, J.). 
doctrine of assumption of risk, the court noted that when the doctrine was first developed in the nineteenth century, "it was applied as a matter of judicial policy to negate an employer's liability for injuries incurred by his employees normally from dangers incident to the work in which engaged." 29

In the area of the employer's liability for employee injuries, the Michigan Legislature dramatically changed the common law rule by its enactment of a workers' compensation law in 1912, and in so doing, it abolished the defenses of contributory negligence, assumption of risk, and the fellow servant rule that had been used to deny recovery by the employee against the employer. ${ }^{30}$

\section{B. The Expansion of Tort Liability in Michigan}

Beginning in the middle of the twentieth century, the Michigan Supreme Court, exercising its constitutional power to make changes in the common law, expanded significantly the scope of tort liability in Michigan. ${ }^{31}$ Emphasizing that "rules created by the court could be altered by the court," and that the court had a "corrective responsibility" when dealing with judge-made law, ${ }^{32}$ the court, in approximately a thirty year period: eliminated the imputed negligence doctrine, under which the driver's negligence was imputed to the passenger in the passenger's suit against a third party; ${ }^{33}$ eliminated charitable immunity as a defense to a tort action; ${ }^{34}$ held that a wife could maintain at tort action for loss of her

29. Felgner v. Anderson, 375 Mich. 23, 32, 133 N.W.2d 136, 141 (1964). During this time, the court also invoked policy considerations in deciding some other questions of tort law, such as its holding that tort actions between spouses were barred by spousal immunity, Bandfield v. Bandfield, 117 Mich. 80, 75 N.W.2d 287 (1898), and holding that a parent's alleged negligence in looking after a child would not be imputed to the child in the child's negligence action against a third party tortfeasor, Battishill v. Humphreys, 64 Mich. 494, 31 N.W. 894 (1887).

30. See the discussion in Felgner, 375 Mich. at 23, 133 N.W.2d at 146. Many years after the abolition of the fellow servant rule, the Michigan Supreme Court concluded that the volunteer doctrine, under which the only duty owed to a volunteer was to refrain from inflicting wilful or wanton injury, was related to the fellow servant rule and was designed to place the volunteer under disabilities similar to those faced by the fellow servant. Saying, "The reasons for the old rule no longer obtaining, the rule falls with it," the Michigan Supreme Court abolished the volunteer doctrine. James v. Alberts, 464 Mich. 12, 18, 626 N.W.2d 158, 162 (2001).

31. Myers v. Genesee County Auditor, 375 Mich. 1, 133 N.W.2d 190 (1965).

32. Placek v. City of Sterling Heights, 405 Mich. 638, 657, 275 N.W.2d 511, 517 (1979).

33. Bricker v. Green, 313 Mich. 218, 21 N.W.2d 105 (1946).

34. Parker v. Port Huron Hosp., 361 Mich. 1, 105 N.W.2d 1 (1960). 
husband's consortium $;{ }^{35}$ abrogated the defense of assumption of risk, which had been applied outside of the employment area ${ }^{36}$ held that there could be recovery for pre-natal injuries, ${ }^{37}$ and finally abolished contributory negligence as a complete bar to recovery in favor of a comparative negligence approach. ${ }^{38}$

In these cases the court discussed the relevant policy considerations influencing its decisions with respect to the common law rule at issue. With respect to the elimination of the imputed negligence doctrine, the court stated:

Ever since 1872 we have adhered to the imputed negligence rule. We have recognized from time to time the changes brought about by the innovations of science and engineering, and we have carefully considered at much length the implications of the rule, its application, and the effect of its abandonment. As a result of our study and observation we are convinced that in the long run the application of the rule is more harmful than helpful and result in more injustice than it prevents. ${ }^{39}$

The justifications for eliminating charitable immunity as a defense to a tort action were that charitable immunity itself was an exception to the general rule of tort liability, that the historical basis for the rule was that it was deemed to advance a sound public policy, and that the reasons for and the consequences of charitable immunity are "not convincing in the light of modern conditions, both in the law and in philanthropy." insurance against tort liability was available to charities, so there was no danger of dissipation of the charity's assets if it was subject to tort liability. Weighted against this was the cost of the victim of bearing the full burden of his injury, so that the arguments for sustaining charitable immunity, "no longer have, if they ever had, compelling effect." ${ }^{, 41}$

The court's holding that a wife could now maintain an action for the loss of her husband's consortium was premised on modern principles of equality of the sexes in the marriage relationship, so that the common law rule allowing a husband to recover for the loss of his wife's consortium was

35. Montgomery v. Stephan, 359 Mich. 33, 101 N.W.2d 227 (1960).

36. Felgner v. Anderson, 375 Mich. 23, 133 N.W.2d 136 (1964).

37. Womack v. Buchhorn, 384 Mich. 718, 187 N.W.2d 218 (1971).

38. Placek v. City of Sterling Heights, 405 Mich. 638, 275 N.W.2d 511 (1979).

39. Bricker, 313 Mich. at 235, 21 N.W.2d at 111.

40. Parker, 361 Mich. at 16,105 N.W.2d at 9.

41. Id. at $18-19,105$ N.W.2d at 10. 
extended in the "line of growth" to allow a wife to recover for the loss of her husband's consortium. ${ }^{42}$ Its holding that a child could recover for prenatal injuries the court recognized that "[1]egal philosophy and precedent have moved in response to scientific and popular knowledge," and concluded that "Michigan should recognize what present day science, philosophy and the great weight of the law in this country consider the better and the sound rule." ${ }^{, 43}$ The court's abrogation of the defense of assumption of risk emphasized that the historical basis of the doctrine was to protect the employer from liability to the employee for work-related injuries, so that the utility of the doctrine was drastically restricted by the adoption of a worker's compensation law, ${ }^{44}$ and that the doctrine served only to relieve a defendant of the legal consequences of his own negligent acts on the theory that the plaintiff assumed the risk of injuries from such negligent acts. ${ }^{45}$

Perhaps the most extensive discussion of policy in these cases was in Placek v. City of Sterling Heights, ${ }^{46}$ where the court abolished contributory negligence as a complete bar in favor of a comparative negligence approach. The court began by noting that, "[t]here is little dispute among legal commentators that the doctrine of contributory negligence has caused substantial injustice since it was first invoked in England in 1809," and that it had been discarded in almost every common law jurisdiction outside of the United States, and by that time had been rejected in favor of some form of comparative negligence in the clear majority of American states. ${ }^{47}$ The court next emphasized that in all the other cases discussed above, the court had exercised a "corrective responsibility" when dealing with judge-made

42. As the court stated in Montgomery:

The Married Women's Acts and common constitutional provisions have wrought a revolutionary change. Legally, today the wife stands on a par with her husband. Factually, as we well know, her position is no less than that of an equal partner. The precedents of the older cases are not valid precedents. They are violative of women's statutory rights and constitutional safeguards. They are out of harmony with the conditions of modern society. They do violence to our convictions and our principles. We reject their applicability. The reasons for the old rule no longer obtaining, the rule falls with it. The obstacles to the wife's action were judgeinvented and they are herewith judge-destroyed.

Montgomery, 359 Mich. at 49, 101 N.W.2d at 234.

43. Womack, 384 Mich. at 724,187 N.W.2d at 222.

44. Felgner v. Anderson, 375 Mich. 23, 41, 133 N.W.2d 136, 146 (1964).

45. Id. at 44,133 N.W.2d at 147 . The application of the doctrine also created confusion with the doctrine of contributory negligence and with the question of whether the defendant's activity amounted to negligence in the first place.

46. 405 Mich. 635, 652, 275 N.W.2d 511, 515 (1979).

47. Id. at 651,275 N.W.2d at 514 . 
law. ${ }^{48}$ Then the court dealt with the question of whether it was appropriate for the courts, rather than the legislature, to change the common law rule of contributory negligence in favor of a rule of comparative negligence. Here the court rejected the oft-asserted claim that the legislature had the superior power of investigating important policy and making an informed choice among available alternatives ${ }^{49}$ It pointed out that the same quantitative data on the impact of comparative negligence on insurance rates and on the processing of claims by settlement that was available to the legislature was likewise available to judges. ${ }^{50}$ In addition, the claim that the legislature could enact change and simultaneously anticipate the numerous details and collateral issues was refuted by the fact that almost all comparative negligence statutes were brief and assigned the courts the responsibility of dealing with ancillary questions. ${ }^{51}$ Finally, the courts could deal with issues of planning and insurability by making decisions that changed the common law prospective in application. ${ }^{52}$ Thus, the court concluded that the courts were "certainly in as good, if not better, a position to evaluate the need for change, and to fashion that change." 53

\section{The Last Quarter-Century: The Question of Where Policy Considerations Lead}

In Berger v. Weber, ${ }^{54}$ decided two years after Placek, a sharply divided Michigan Supreme Court held that Michigan would recognize a common law action by a child for loss of a parent's consortium caused by a negligent injury, making Michigan only the second state to do so at that time. What is significant about Berger for present purposes is that both the majority and

\footnotetext{
48. Id. at 657,275 N.W. $2 \mathrm{~d}$ at 517 .

49. Id.

50. Id.

51. Id.

52. Placek, 405 Mich. at 657,275 N.W.2d at 517.

53. Id. at 659,275 N.W.2d at 518 . The court in Placek adopted a pure comparative negligence approach, under which the plaintiff's recovery is reduced by the percentage of the plaintiff's own fault, so that, for example a plaintiff who is deemed $60 \%$ at fault and who suffered $\$ 100,000$ in damages still will recover $\$ 40,000$. The court noted that the Michigan Legislature "has the power to reinstate contributory negligence or to modify this rule of comparative negligence." Id. at $662 \mathrm{n} .12,275 \mathrm{~N} . \mathrm{W} .2 \mathrm{~d}$ at $520 \mathrm{n}$.12. In 1995, as part of the process of tort reform, the Michigan Legislature provided for comparative negligence by statute, and while retaining pure comparative negligence with respect to economic damages, it prohibited recovery for non-economic damages where the plaintiff's proportion of fault was greater than the aggregate fault of the other person or persons. MICH. COMP. LAWS ANN. $\S 600.2959$ (West 2000 \& Supp. 2007).
}

54. 411 Mich. 1, 303 N.W.2d 424 (1981). 
the dissent approached the issue almost entirely with reference to considerations of policy. The majority opinion by Justice Kavanagh stated: "We are satisfied that existing judicial and legislative policies warrant recognizing a child's cause of action for loss of society and companionship of a negligently injured parent." 55 Looking to what we have called the "line of growth" of the common law, the majority emphasized that allowing the child to maintain a cause of action for loss of a parent's consortium advanced the same interests that were advanced by allowing spouses to maintain a cause of action for loss of the other spouses consortium, and that children could recover for the loss of society and companionship of a parent who was negligently killed under the wrongful death act. ${ }^{56}$ The majority rejected the defendant's argument that it should not recognize the cause of action because of the economic burden to the public due to increased insurance premiums, saying that compensating a child who has suffered emotional problems because of the deprivation of a parent's love and affection could provide the child with the means of adjustment to the loss, and that since society would also benefit if the child is able to function without emotional handicap, "this may well offset any increase in insurance premiums." 57

The dissent, in contrast, invoked policy considerations as a justification for not recognizing the cause of action. Justice Levin, writing for the dissenting justices, set out the policy arguments advanced on both sides of the issue, and noted: "[d]ecisions delineating the extent of tort liability are, however, more than exercises in logic. They are pronouncements of social policy, which should reflect the often subtle balance of the interests involved." ${ }^{8}$ This being so, Justice Levin stated that: "[t]oday we balance the interest of an injured person's child in monetary redress for injury to the parent-child relationship against the consequences of imposing yet another potential liability upon a negligent defendant a liability the additional cost of which will be spread among the citizens of the state through increased insurance premiums. ${ }^{.59}$ The dissenters emphasized the anomaly of allowing any action for loss of consortium - the plaintiff recovers damages for an

55. Id. at 13,303 N.W.2d at 425 .

56. Id. at $14-15,303$ N.W. $2 \mathrm{~d}$ at $425-26$.

57. Id. at 15,303 N.W. $2 \mathrm{~d}$ at 426 . In response to the argument that the court should "leave the matter to the legislature," the court observed that, "[a]t the present time, children are prevented from recovering for loss of parental consortium by judicial decision," and "[w]e do not regard the cause of action contemplated here so complex that we should defer action to the Legislature." Id. at 17, 303 N.W.2d at 427.

58. Id. at 23-24, 303 N.W.2d at 430 .

59. Berger, 411 Mich. at 24, 303 N.W.2d at 430. 
injury to another person-and said that this was a good reason for not extending it beyond the marriage relationship to other relationships. ${ }^{60}$ The dissent concluded as follows:

In concluding that the balance between the child's interest in compensation for the lost society and companionship of an injured parent and the tortfeasor's interest in freedom from additional liability, with due consideration to the social consequences of each alternative, weighs against recognition of a child's claim, we are influenced by a number of considerations including the uncertainty that recognizing the proposed cause of action will yield a significant social benefit, the additional economic burden imposed upon the general public by expanding recovery to a new category of indirect injury likely to be associated with a large percentage of accidents, the nature of the loss asserted, the lack of immediate connection between the plaintiff and the defendant, and the difficulty of objective demonstration and evaluation of the child's injury. ${ }^{61}$

This case demonstrates very clearly not only that policy considerations have always been a part of the development of the common law in Michigan, but that members of the court can sharply disagree on the place where policy leads the common law and on the result that follows from the court's application of policy in the particular case. The matter of disagreement over where policy leads in a particular case will surface again in the discussion of Henry and a cause of action for medical monitoring.

The development of the common law in a line of growth and the relevance of policy considerations in that development is illustrated by the court's decisions in regard to comparative fault following its adoption of the comparative fault approach in place of the contributory negligence approach. In order to counter some of the harshness of the contributory negligence approach, the Michigan Supreme Court grafted some exceptions on to the contributory negligence doctrine, such as last clear chance and gross negligence. With the abolition of the contributory negligence approach, the court abrogated these doctrines too. ${ }^{62}$ In addition, the court, asserting its "obligation to analyze and decide the issues presented by applying the common-law principles of negligence developed in our prior

60. Id. at 29,303 N.W.2d at 433.

61. Id. at 33,303 N.W. $2 \mathrm{~d}$ at 435 .

62. See Jennings v. Southwood, 446 Mich. 125, 521 N.W.2d 230 (1994); Petrove v. Grand Trunk W. R.R. Co., 437 Mich. 31, 464 N.W.2d 71 ! (1991). 
decisions in a consistent manner," held that evidence of a driver's failure to use a seat belt was admissible in an automobile accident or products liability case to show the driver's comparative fault. ${ }^{63}$

The development of the common law in a line of growth, and the relevance of policy considerations in that development in Michigan, is further illustrated by the application of the open and obvious doctrine by the Michigan Supreme Court. The rationale of the open and obvious doctrine is that the defendant should not be held liable for harm caused by a danger that was open and obvious to the person suffering the harm. The doctrine was first asserted by a manufacturer in a design defect case, where the claim was that the design of a forklift was defective for failing to provide some sort of factory-installed driver restraint that would have prevented the driver's ejection during a rollover. ${ }^{64}$ The manufacturer argued that it should

63. Lowe v. Estate Motors, Ltd., 428 Mich. 439, 449, 410 N.W.2d 706, 710 (1987). In that case, which involved a products liability claim, the evidence of failure to use a seat belt could also be introduced for the purpose of defending the crashworthiness design of the vehicle.

The court also dealt with the fact that the Legislature had recently enacted mandatory seat belt usage legislation, MiCH. COMP. LAwS ANN. $\S 257.710 \mathrm{e}$ (West 2001), which required drivers and front-seat passengers to wear seat belts and further provided that the failure to use the seat belt in violation of the statute could be considered negligence, but that such negligence would not reduce the plaintiff's recovery by more than $5 \%$. The statute did not apply to the case at bar, both because the accident occurred prior to the statute's effective date and because the plaintiff was a rear seat passenger to whom the statute would not apply. The court majority concluded that it should not engage in "legislative deference" in deciding what the common law rule should be, and that it was appropriate for the court to apply the comparative negligence doctrine to failure to use a seat belt without regard to the legislative standard. The result was that in a tort suit, there were two alternative grounds for admitting evidence of the failure to use a seat belt, the statute or the common law rule. The difference was that when the evidence of failure to use a seat belt was admitted under the statute, the 5\% limit applied, but when the evidence was admitted under common law negligence, neither the conditions of the statute nor the $5 \%$ limit applied. This difference was discussed by the Michigan Supreme Court in Mann v. St. Clair County Road Comm'n, 470 Mich. 347, 350, 681 N.W.2d 653, 656 (2004). The court then went on to hold that the statute's cap on the reduction of damages applied only to the limited tort actions that could be brought under the no-fault act, MiCH. COMP. LAWS ANN. §§ 500.3101-.3179 (West 2002). So, in the products liability or automobile accident case brought against the alleged tortfeasor, the matter is governed by the common law comparative negligence doctrine, and evidence of the failure to use a seat belt is admissible to show comparative fault on the part of the driver or passenger and to reduce recovery accordingly. It should be noted in this regard that the statute enacted to incorporate the court's change of the common law from a contributory negligence to a comparative negligence approach, MICH. COMP. LAWS ANN. $\S 600.2959$ (West 2000 \& Supp. 2007), retains pure comparative negligence with respect to economic damages, but prohibits recovery for non-economic damages where the plaintiff's proportion of fault was greater than the aggregate fault of the other person or persons.

64. Owens v. Allis-Chalmers Corp., 414 Mich. 413, 425, 326 N.W.2d 372, 377 (1982). 
not be liable because the alleged defect was obvious to the driver of the forklift. ${ }^{65}$ The court held that the open and obvious doctrine was inapplicable in a design defect claim, stating that, "[o]bvious risks may be unreasonable risks, and there is no justification for departing from general negligence and breach of warranty principles merely because the dangers are patent." whether the risks are obvious, but whether the risks were unreasonable in light of the foreseeable injuries."

However, the court next held that the doctrine was applicable in a failure to warn case, where the claim was that the manufacturer of an aboveground pool was negligent in failing to inform the user of the danger of a headfirst dive into the shallow waters of the pool. ${ }^{68}$ The premises of duty to warn liability in products cases, said the court, is that sellers have an obligation to transmit safety-related information when they know or should know that the buyer or user is unaware of that information. ${ }^{69}$ The court concluded that the manufacturer had no duty to warn of open and obvious dangers connected with the use of an otherwise non-defective product that were discoverable upon casual inspection by the average user of ordinary intelligence. ${ }^{70}$ In such a situation, the court concluded, the policies served by duty to warn liability are absent, and for this reason there is no duty to warn. ${ }^{71}$

Once the court held that there was no duty to warn of open and obvious dangers in products liability cases, it was a short step to extend the holding to premises liability cases, and the Michigan Supreme Court did so. Here the open and obvious doctrine was recast to include a "special aspects" exception. Thus, the common law rule relating to the duty owned by an owner of land to an invitee in Michigan is that the premises' possessors are not required to protect the invitee from open and obvious dangers, but if special aspects of a condition make even an open and obvious risk unreasonably dangerous, the possessor has a duty to undertake reasonable

65. Id.

66. Id.

67. Id. In regard to the reasonableness issue in the particular case, the Court observed that the focus solely was on the forklift and that the question was whether a forklift was unreasonably dangerous when it failed to include a factory-installed driver restraint such as a seat belt or a cage enclosure. Id. at 428,326 N.W.2d at 378 .

68. Glittenberg v. Doughboy Recreational Indus., 441 Mich. 379, 491 N.W.2d 208 (1992).

69. Id.

70. Id.

71. Id. 
precautions to protect invitees from that risk. ${ }^{72}$ As the court explained the doctrine in its application to premises liability:

[W]ith regard to open and obvious dangers, the critical question is whether there is evidence that creates a genuine issue of material fact regarding whether there are truly "special aspects" of the open and obvious condition that differentiate the risk from typical open and obvious risks . . . i.e., whether the "special aspect" of the condition should prevail in imposing liability upon the defendant or the openness and obviousness of the condition should prevail in barring liability. ${ }^{73}$

At the same time, the Court has recently held that the open and obvious doctrine did not apply to negligence claims against a general contractor with respect to a common work area. ${ }^{74}$ In this situation, two common law doctrines, the common work area doctrine, and the open and obvious doctrine, which are founded on different policy considerations, appeared to clash. Under the common work area doctrine in Michigan, the general contractor on a construction project has the duty to assure that reasonable steps, within its supervising and coordinating authority, are taken to guard against readily observable and avoidable dangers in common work areas that create a high degree of risk to a substantial number of workers. ${ }^{75}$ In order for the general contractor to be liable under the common work area doctrine for the negligence of the employees of independent subcontractors with respect to job site safety, the plaintiff must show that the general contractor failed to take reasonable steps within its supervisory and coordinating authority to guard against readily observable and avoidable dangers, and that the general contractor's failure to do so created a high degree of risk to a significant number of workers in a common work area. ${ }^{76}$ The policy reasons for the common work area doctrine are that in many

72. Lugo v. Ameritech Corp., Inc., 464 Mich. 512, 517, 629 N.W.2d 384, 386 (2001). The first case to apply the open and obvious doctrine to claims of premises liability was Bertrand v. Alan Ford, Inc., 449 Mich. 606,537 N.W.2d 185 (1995). In that case, one of the plaintiffs tripped on a step outside a park restroom, and the only basis for her claim was that she failed to see the step. The court held that recovery was barred under the open and obvious doctrine. In another case, again involving a fall from a step, the court found that there was a question of fact concerning "special aspects," since "the construction of the step, when considered with the placement of the vending machines and the cashier's window, along with the hinging of the door, created an unreasonable risk of harm, despite the obviousness of the invitee's knowledge of the danger of falling off the step." Id.. at 624, 537 N.W.2d at 192.

73. Lugo, 464 Mich. at $517-518,629$ N.W.2d at 387.

74. Ghaffari v. Turner Constr. Co., 473 Mich. 16, 699 N.W.2d 6877 (2005).

75. Funk v. General Motors Corp., 392 Mich. 91, 220 N.W.2d 641 (1974).

76. Ormsby v. Capital Welding, Inc., 471 Mich. 45, 54, 684 N.W.2d 320, 325-326 (2004). 
cases only the general contractor is in a position to coordinate the work or provide expensive safety features that protect the employees of many or all of the subcontractors, and that even if subcontractors and supervisory employees are aware of safety violations, they are often unable to rectify the situation themselves or are in too poor an economic position to compel their superiors to do so. ${ }^{77}$ And, of course, the individual employee must either continue to work despite awareness of the safety violations or give up the employment.

The court went on to say that there was an irreconcilable conflict between the common work area doctrine and the open and obvious doctrine, since the common work doctrine imposes an affirmative duty on the general contractor to protect against open and obvious hazards on the construction project, while the open and obvious doctrine imposes no duty on the defendant if the hazards are open and obvious. ${ }^{78}$ The court then found that the doctrines were distinct in that the open and obvious doctrine applied to a premises' possessor, while the common work doctrine applied to a general contractor whose responsibility it was to coordinate the activities of an array of subcontractors and different duties were imposed under the different doctrines..$^{79}$ In addition, applying the open and obvious doctrine in the construction setting would nullify the doctrine of comparative negligence in that setting and would effectively restore the complete bar to a contractor's liability that was abolished when comparative negligence replaced contributory negligence. ${ }^{80}$ The court thus concluded that the open and obvious doctrine has no applicability to a claim under the common work area doctrine. ${ }^{81}$

\section{Judicial Policymaking in Michigan: Some Further Observations}

It has been demonstrated, therefore, that in the development of the common law of Michigan, the Michigan Supreme Court has at all times engaged in judicial policymaking. From the liability-limiting rules of the late nineteenth century designed to protect the newly-emerging industries in this state, to the court's exercise of its power to change the common law in Michigan over a thirty year period by expanding significantly the scope of tort liability in Michigan, to its recognition of new claims, such as a child's right to recover for loss of a parent's consortium caused by a negligent injury, to its imposition of limits on tort recovery, such as the open and obvious doctrine, the court has invoked considerations of policy

77. Funk, 392 Mich. at 104, 220 N.W.2d at 646.

78. Ghaffari, 473 Mich. at 21,699 N.W.2d at 691.

79. Id. at 23-24, 699 N.W.2d at 691-92.

80. Id. at $25-26,699$ N.W.2d at 693 . Comparative negligence was held to replace contributory negligence in the construction setting in Hardy v. Monsanto Enviro-Chem Systems Inc., 414 Mich. 29, 323 N.W.2d 270 (1982).

81. Ghaffari, 473 Mich. at 25-26, 699 N.W.2d at 693. 
in support of its decisions. In these cases, the court's invocation of policy considerations was sometimes accompanied by substantial disagreement among members of the court over where policy should lead. Moreover, at no time did the court ever suggest that separation of powers considerations should somehow operate as a kind of prudential restraint on the court's use of policy in the development of the common law, or on the court's ability to promulgate common law rules that will bring about, to use Justice Corrigan's term in Henry, a "dramatic reallocation of societal benefits and burdens. " ${ }^{82}$ It is this judicial policymaking that has marked the development of the common law throughout the United States. The history of the development of the common law has been a history of judicial policymaking, and as Oliver Wendell Holmes pointed out long ago: "Every important principle which is developed by litigation is in fact and at bottom the result of more or less definitely understood views of public policy. ${ }^{183}$

It is further submitted that Justice Young is quite wrong when he says that policymaking is exclusively the province of the legislature, that the courts cannot formulate common law rules that may have significant social and economic effects, and that the courts should not make a "new and potentially societally dislocating change to the common law." also disagreement with Justice Corrigan's contention that separation of powers considerations may operate as a prudential bar to judicial policymaking in the common law arena. ${ }^{85}$ Quite to the contrary, it is submitted that the Michigan courts, in exercising the judicial power conferred upon them by the Michigan Constitution, must develop the common law of Michigan and, as necessary, engage in judicial policymaking in the formulation of common law rules. The legislature has the power to change the common law by legislation and to substitute its policy choices for those that the court has made.$^{86}$ But unless and until the legislature has done so, it is the common law that determines the legal rights and obligations of private persons in Michigan, and just as the legislature makes policy choices in enacting legislation, the courts also make policy choices in formulating the common law. This is their power and responsibility under the Michigan Constitution. ${ }^{87}$

82. Henry, 473 Mich. 63, 701 N.W.2d 684.

83. Holmes, THE CoMmON LAw, supra note 22. note 6.

84. Young, "State Jurisprudence, the Role of the Courts and the Rule of Law, "supra,

85. Henry, 473 Mich. at 88,701 N.W.2d at 697.

86 . Thus, the courts cannot promulgate a common law rule that expressly conflicts with the provisions of legislation, nor may they formulate a common law rule in an area that has been effectively preempted by legislation. See the discussion, supra, note 15 , and accompanying text.

87. As stated previously, the difference between what the courts do and what the legislature does is a difference in process, not a difference in substance. 


\section{The Michigan SUPREME COURT DECISION IN HENRY v. DOW CHEMICAL}

We now turn to the Michigan Supreme Court's decision in Henry $v$. Dow Chemical. ${ }^{88}$ This was a class action brought by plaintiffs seeking to represent a putative class of thousands against Dow Chemical. The core allegation was that Dow's plant in Midland, Michigan, negligently released dioxin, a synthetic chemical that is potentially hazardous to human health, into the Tittabawasee flood plain where the plaintiffs and the putative class members lived and worked. The plaintiffs asked the court to certify a class that collectively sought the creation of a program, to be funded by the defendant and supervised by the court, that would monitor the class and their representatives for possible future manifestations of dioxin-related disease. $^{89}$

The court held that the plaintiffs' medical monitoring claim was not cognizable under Michigan law. ${ }^{90}$ The court said that the claim was not a viable claim for negligence as it currently existed because the plaintiffs did not allege a present physical injury, ${ }^{91}$ and the court was unwilling to modify Michigan's common law to encompass a cause of action for medical monitoring.

Although recognizing that "the common law is an instrument that may change as times and circumstances require," the court stated that it would not alter the common law of negligence liability to encompass a cause of action for medical monitoring. ${ }^{92}$ The court gave two reasons in support of its decision. First, the court said that recognition of a medical monitoring claim would involve extensive fact-finding and the weighing of numerous and conflicting policy concerns, and that the court lacked sufficient informaticn to assess intelligently and fully the potential consequences of recognizing a medical monitoring claim. ${ }^{93}$ Second, and equally important said the court, was that:

[P]laintiffs have asked this Court to effect a change in Michigan

88. Henry, 473 Mich. at 88,701 N.W.2d at 697.

89. The facts are taken from the court's opinion. Henry, 473 Mich. at 67,701 N.W. $2 \mathrm{~d}$ at 685-686.

90. Id. at 82,701 N.W.2d at 694 .

91. As to the first point, the court said that under well-established common law principles, the imposition of tort liability requires a showing of a present physical injury to persons or property, and at this point in time, the release of dioxin into the flood plain has not caused present physical injury to the plaintiffs. Id. Tort liability should not be extended to the possibility of future harm that may never occur. Id. The only injury that the plaintiffs presently were suffering was the fear of a future illness and the costs of medical monitoring, which were not sufficient to satisfy the requirement of a present physical injury. Id. The court thus concluded that the plaintiff's claim for medical monitoring could not stand under the common law of negligence as it currently existed in Michigan. Id.

92. Henry, 473 Mich. at 68,701 N.W.2d at 686.

93. Id. 
law that, in our view, ought to be made, if at all by the legislature ... [and] [a]s a matter of prudence, we defer in this case to the people's representatives in the Legislature, who are better suited to undertake the complex task of balancing the competing societal interests at stake. ${ }^{94}$

With respect to the first reason, the court said that judicial recognition of such a claim based solely on exposure without a requirement of present injury could have "undesirable effects that neither we nor the parties can satisfactorily predict," such as creating a potentially limitless pool of plaintiffs and draining resources needed to compensate those with manifest physical injuries and a more immediate need for medical care. ${ }^{95}$ The court went on to say that it was not clear that the benefits of a medical monitoring cause of action would outweigh the burdens imposed on plaintiffs with manifest injuries, the judicial system, and those responsible for administering and financing medical care. ${ }^{96}$ Because of the asserted need for extensive fact-finding and the weighing of numerous and conflicting policy concerns, the court concluded that, "we do not believe that the instant question is one suitable for resolution by the judicial branch. ${ }^{.97}$

The dissenting justices argued that the plaintiffs did suffer actual harm and damages in the form of heightened exposure to dioxin that they had received because of defendant's acts and that if it were not for defendant's acts, plaintiffs would not have been advised to incur the expenses involved in additional testing for early detection of any illnesses caused by the increased dioxin exposure. The defendant should be responsible for paying for the costs of the tests, they said, because the defendant was responsible for the need for the test. ${ }^{98}$ The dissenting justices obviously did not share the majority's concerns about the unpredictable consequences that could result from recognizing a cause of action for medical monitoring. The dissent argued that this was a clear case of heightened exposure to a dangerous substance that caused harm to particular plaintiffs, that

94. Id. at $68-69,701$ N.W. $2 \mathrm{~d}$ at 686 . The court noted that the legislature had already established policy in this area by delegating the responsibility for dealing with the health risks stemming from industrial pollution to the Michigan Department of Environmental Quality.

95. Id. at 83,701 N.W. $2 \mathrm{~d}$ at 694 .

96. Id. at 84,701 N.W.2d at $694-95$.

97. Id., 701 N.W.2d at 695.

98. Id. at 107-08, 701 N.W.2d 707 (dissenting opinion). The dissent pointed out that the plaintiffs had been exposed to dioxin at over 80 times the level deemed safe for direct residential contact and that routine activities, such as flower gardening and lawn work could further increase their risk of dioxin exposure. They were advised that they should not allow their children to play in the soil to avoid further contamination. Unlike any exposure to dioxin, these plaintiffs are at much greater risk than other persons. Because of the prolonged exposure to high levels of dioxin, a doctor may, according to accepted scientific principles, find that such tests are reasonably necessary to best monitor and treat a patient. 
recognizing a cause of action for medical monitoring on these facts would not allow a claim for medical monitoring resulting from any kind of harmful exposure, and that the plaintiffs were seeking only a limited remedy for the harm caused by the defendant. ${ }^{99}$ And other courts have recognized a cause of action for medical monitoring along the lines of the claim asserted by the plaintiffs in Henry. ${ }^{100}$

At this point in the opinion, the result can be explained in terms of a sharp difference between the majority and the dissent over the place where policy leads the common law and on the result that follows from the court's application of policy in the particular case. We saw this kind of sharp policy disagreement among the members of the court in Berger v. Weber, ${ }^{101}$ on the question of whether Michigan should recognize a common law action by a child for loss of a parent's consortium. ${ }^{102}$ These disagreements are also reflected in the dissenting opinions in some other cases where the Michigan Supreme Court made changes in the common law of Michigan, such as when it abolished charitable immunity, ${ }^{103}$ and when it held that a wife could maintain a tort action for loss of her husband's consortium. ${ }^{104}$ This would simply be another case where the Michigan courts, in exercising the judicial power conferred upon them by the Michigan Constitution, have developed the common law of Michigan and as necessary, have engaged in judicial policymaking in the formulation of common law rules. The majority's application of judicial policymaking in Henry led to its conclusion that considerations of policy should cause it to refuse to recognize a cause of action for medical monitoring.

But the court did not stop at this point. Instead, Justice Corrigan, writing for the court, invoked the hitherto unknown proposition that "separation of powers considerations may operate as a prudential bar to judicial policy-making in the common-law arena." 105 According to Justice Corrigan, "[t]his is so when we are asked to modify the common law in a way that may lead to dramatic reallocation of societal benefits and burdens." 106 With all due respect, there is nothing in constitutional separation of powers considerations that imposes any kind of limitation on the constitutional responsibility of the Michigan Supreme Court to promulgate the common law of Michigan, and as necessary, to engage in judicial policymaking in the process of doing so. As has been demonstrated

99. Henry, 473 Mich. at 106-21, 701 N.W.2d at 707-715 (dissenting opinion). 100. See Hansen v. Mountain Fuel Supply Co., 858 P.2d 970 (Utah 1993); Bower v. Westinghouse Electric Corp., 206 W.Va. 133, 522 S.E.2d 424 (1999).

101. Berger, 411 Mich. 1, 303 N.W.2d 424.

102. See the discussion, supra note 57 , and accompanying text.

103. Parker, 361 Mich.1, 105 N.W.2d 1. The decision in that case was 4-3.

104. Montgomery, 359 Mich. 33, 101 N.W.2d 227. The decision in that case was also 4-3.

105. Henry, 473 Mich. at 89,701 N.W.2d at 697.

106. Id. at 89,701 N.W.2d at 697 . 
repeatedly, the history of the development of the common law has been a history of judicial policymaking. Justice Corrigan's concern about the court's "modify[ing] the common law in a way that may lead to dramatic reallocation of societal benefits and burdens" 107 completely ignores the "dramatic reallocation of society benefits and burdens" 108 that took place in Michigan when the court, beginning in the middle of the twentieth century, abandoned the tort liability-limiting rules of the late nineteenth century that had been promulgated to protect the newly-emerging industries (and that put the burden of industrial accidents on victims and employees, thereby benefitting manufacturers and employers), and expanded significantly the scope of tort liability in Michigan. As this process was taking place, it was never suggested that separation of powers concerns had any relevance at all when the court was exercising its constitutional responsibility to promulgate the common law of Michigan, or that somehow the court was to defer to the legislature and avoid engaging in "judicial policymaking." 109 Again with all due respect, there is strong disagreement with Justice Corrigan's position that separation of powers considerations in any way preclude the court from engaging in "judicial policymaking" as it promulgates the common law of Michigan.

As has been discussed earlier, separation of powers considerations constrain the power of the courts to promulgate common law rules in two ways. First and most obviously, since under the Michigan Constitution legislation takes precedence over the common law, the courts may not formulate a common law rule the expressly conflicts with the provisions of legislation. Second, the courts may not properly promulgate a common law rule that has been effectively preempted by legislation. But that is all. It is the legislature's constitutional responsibility to legislate. It is the court's constitutional responsibility to promulgate common law rules. So long as there is no express conflict between legislation and a common law rule, and so long as there has been no preemption, the courts may promulgate common law rules regulating the rights of private persons in areas where the legislature has enacted regulatory legislation.

In a case such as Henry, where the court holds, as it did in the first part of the Henry opinion, that policy considerations preclude recognition of a new kind of tort liability, it follows that if such liability is going to be imposed, it will have to be imposed by the legislature. But this is not because the court has somehow deferred to the legislature with respect to the matter in issue. It is because the court has refused to promulgate a new common law rule at the present time. Liability could be imposed by legislation if the legislature decides to impose such liability at a future time,

108. Id.

109. The court emphasized that "rules created by the court could be altered by the court," and that the court "had a corrective responsibility when dealing with judge-made law." Placek, 405 Mich. at 657, 275 N.W.2d at 517. 
or it could be imposed by the court at a future time if the court considers the matter anew.

In Henry, the court made much of the fact that the legislature had provided a method for dealing with the negligent emission of toxic substances by giving the Michigan Department of Environmental Quality broad regulatory authority to deal with the kind of environmental and health risks brought about by Dow's alleged emission of dioxin into the Tittabawassee flood plain. ${ }^{110}$ The court said that the plaintiffs were asking the court to create a cause of action for medical monitoring where the legislature has already signaled its preference with respect to the appropriate form a remedy should take. The court concluded that, "[i]n deference to the policy-making branch of our government, we decline to create this alternative remedial regime." 111

This statement, it is submitted, is inconsistent with the constitutional responsibility of the Michigan Supreme Court to promulgate the common law of Michigan. In the exercise of its constitutional responsibility to promulgate the common law of Michigan, the Michigan Supreme Court must, and throughout its history has, engage in judicial policymaking. Under our constitutional scheme then, both the Michigan Legislature and the court engage in policymaking. The difference between what the court does and what the legislature does is a difference in process, not a difference in substance. The court engages in policymaking through the judicial process while the legislature engages in policymaking through the legislative process. While the processes are quite different, they are both provided for under the Michigan Constitution, and the court cannot abandon its constitutional responsibility to promulgate the common law merely because the legislature also has legislated with respect to the matter in issue. Since allowing a cause of action for medical monitoring for toxic harm would in no way interfere with the legislative scheme for dealing with the negligent emission of toxic substances such as dioxin, it is entirely appropriate for the court to promulgate a common law rule recognizing such a claim.

But as has been discussed previously, the Michigan Supreme Court in Henry set forth valid policy reasons for refusing to promulgate a common law rule recognizing a cause of action for medical monitoring. The dissent argued that policy reasons justified the promulgation of such a rule. The courts can disagree over questions of where policy should lead, as they can disagree over any other question, but this disagreement, as disagreement in other areas, in no way affects the appropriateness of judicial policymaking. 


\section{CONCLUSION}

It is submitted, therefore, that it is the responsibility of the Michigan Supreme Court to promulgate the common law of Michigan, and when it is necessary to do so, to engage in judicial policymaking. It is not consistent with the constitutional responsibility of the Michigan Supreme Court to defer to the legislature and to refuse to promulgate an otherwise appropriate common law rule on the ground that this "may lead to a dramatic reallocation of societal benefits and burdens." It may be hoped that the part of the Henry opinion proposing such deference will be regarded as an unnecessary aberration and will not become a part of the constitutional law of this state. 